\title{
促通反復療法を訓練用ロボットに活かす 一効率的な神経路の再建強化を目指してー
}

\author{
川平和美 ${ }^{1 \dagger}$ \\ ${ }^{1}$ 促通反復療法研究所
}

\begin{abstract}
要旨：脳卒中治療ガイドライン 2015 「推奨する」とされた促通反復療法は, 治療者が目標の神経路の興奮水準を高める ことによって患者の意図した運動の実現と反復を可能にした。これによって，これまで難しかった個々の指の運動性下行 路まで効率的に再建・強化ができるようになった，その効果の科学的検証では脳卒中患者の麻痺や麻痺側上肢での物品操 作能力, 歩行, ADL の改善が証明されている. 基本的な治療理論と実際の手法を上肢と歩行について紹介し, 訓練用ロボッ トへの応用や低周波電気刺激や振動刺激などとの併用療法についても紹介したい.
\end{abstract}

キーワード : 片麻疩, 促通反復療法, ロボット, 電気刺激, 振動刺激

\section{1.はじめに}

脳卒中や脊䯣損傷による麻痺を回復させるニューロリハ ビリテーション（ニューロリハ）は目覚ましく発展してい るが, リ八科医や理学療法士, 作業療法士などリ八関連職 種への普及が遅れているため, 最新のニューロリ八を期待 して入院した麻疩患者と家族の失望と落胆を招いているリ 八施設が少なくない。

a）片麻痺回復のメカニズム

ここでは, 麻痺の回復が難しいと考えられてきた片麻疩 上肢の手指について神経路の再建について新たな可能性を 示す ${ }^{1)}$.

手指の運動は対側半球の運動野からの神経路（皮質脊䯣 路）の支配を受けているため, 健側半球からの同側支配の 神経路で機能改善を図ることが難しく, 他の下肢や躯幹な どの身体部位とは区別されることが多かった．しかし，運 動野が広く損傷された場合でも損傷部からの対側支配の皮 質脊髄路に替わって, 颈䯣で健側半球からの対側支配の皮 質脊髄路から神経側芽が伸びて手指の前角細胞と結合して, 健側半球からの支配によって手指の麻疩が改善する ${ }^{2}$.

脳卒中片麻疩例の手指の機能回復を例に挙げて, 原則的 な考元方を説明する. 神経路の強化と再建（形成）は, 図 1 に示すように, ヘップ理論にしたがっており，（1）繰り返 し興奮を伝えた神経路は強化される，(2) 同時に興奮した 神経路は結合しやすいとの原則に従っている ${ }^{3)}$.

2018 年 2 月 23 日受付

† $150-0041$ 東京都淽谷区神南 1-12-10 促通反復療法研究所 (川平先端リハラボ) 川平和美

Tel: 03-6455-1373

E-mail: kawahirarfe@gmail.ac.jp
患者が麻疩手の「示指を伸ばそう」としても動かない場 合, 図 1 の左側の状態で大脳皮質からの運動努力（興奮）は 途中で止まっている. しかし，患者の運動努力に合わせた 操作（伸張反射や電気刺激, 振動刺激）によって, (a) 受 け手側の神経路への興奮伝達を実現する, あるいは（b) 示 指を伸ばす脊䯣前角細胞を含む神経路を興奮させることが できれば，図 1 右側のように大脳皮質からの運動努力が菲 髄前角細胞を興奮させて患者の意図した運動「示指を伸ば す」を実現する。もし，大脳の運動努力による「示指を伸 ばす」が実現しなくても，大脳皮質からの運動努力（興奮） と受け手側の神経路の促通操作による興奮が一致していれ ば，この2つの神経路は繋がり易いので，促通操作を繰り 返せば神経路の形成と強化が進み麻疩は改善する。

しかしながら，これまでのニューロリハでは，麻疩手の 機能回復のためには麻痺した手指を繰り返し曲げ伸ばしす

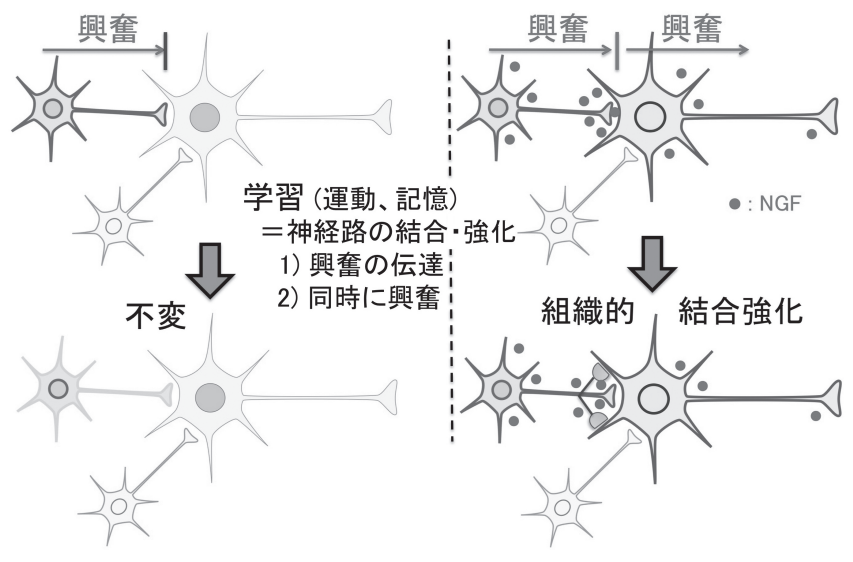

図 1 神経路の結合と強化の理論 (ヘップの理論) 神経路の強化や結合はシナップスの可塑性が背景にあり, 興奮伝達 を繰り返す神経路は強化され, 興奮のタイミングが同期している神 経路は繋がりやすい. 
ることを求める, あるいは麻瘏の程度には関係なく麻痺手 で円錐型のプラスチックコーンを掴み移動させることを求 めるリハが多く行われ, 麻痺が重度で思い通りに指が動か せない例には作業療法士が介助して他動運動に近い形で指 の屈伸や物品操作を行っている.

「日本の脳卒中ガイドライン 2015」4) では上肢麻疩への治 療として指や手関節をある程度動かせる例には, 非麻痺上 肢をミトンなどで使えないようにして 4 時間の麻瘏手での 物品操作を求める CI が強く推奨され, 促通反復療法が推奨 されているが ${ }^{4)}$, 患者負担の軽減と治療効率の向上を工夫 する必要がある。

今後のリ八に求められることは, 患者に求めている膨大 な試行錯誤を可能な限り減らして, 再建・強化したい目標 の神経路に患者の運動努力を伝えられる高い治療効率（治 療効果 / 治療時間）のリハの確立である。これを実現する手 法は治療者が患者に目標の運動を指示し, 患者の運動努力 の直前に目標の運動実現に関与する神経路の興奮を高める 促通操作（促通反復療法や電気刺激, 振動刺激）を行って, 患者の運動努力がその神経路に伝わり目標の運動を確実に 実現できる手法である.

つまり, 図 2 に示すように, 迷路の中にある患者の運動努 力の出口 (目標の神経路) を治療者が教えて試行錯誤なし に患者の意図した運動を実現することである ${ }^{1)}$.

\section{2. 促通反復療法の治療理論と手技}

促通反復療法の治療理論と促通操作の意味の理解を容易 にするため, 片麻痺の上肢ならびに下肢と歩行に分けて説 明する。

\section{1 片麻痺上肢}

これまで効果的なリハがなかった麻痺手の個々の手指の

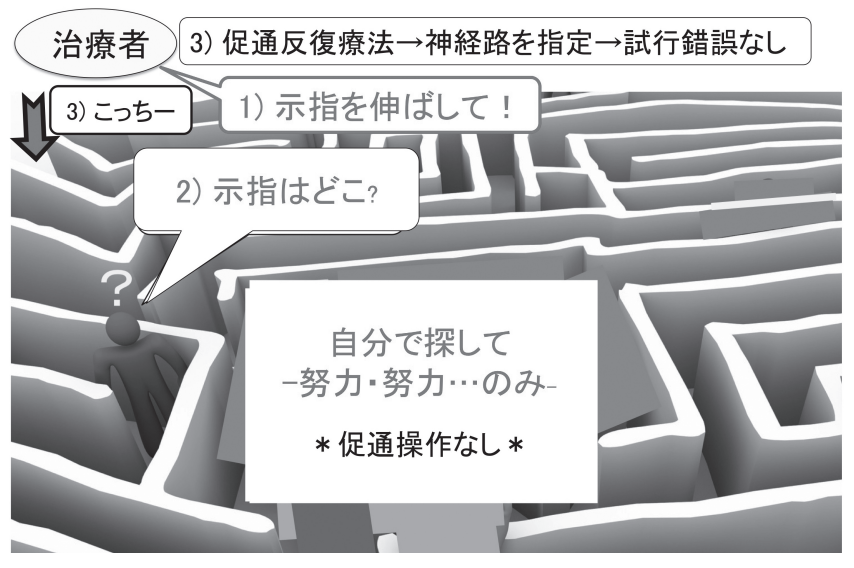

図 2 治療者が出口（神経路）を指定 治療者が患者に「麻痺手の示指を伸ばして」と指示した時, 患者は 示指だけを伸ばす努力を行うが, 他の指も動いてしまうので, 試行 錯誤を繰り返す。治療者が促通操作で目標の神経路（出口）を教え れば示指の伸展が実現する。
運動を回復する手法を, 母指から小指の伸展はできるが個々 の指の伸展ができない例（BRS: IV）を用いて説明する.

患者は示指のみを伸展させようとするが, 実際に生じる 運動は母指から小指までが同時に伸展して, 示指だけを伸 展することができない，治療者は，図 3 に示すように，患 者の示指を素早く屈曲させること（伸張反射）によって示 指の伸展（意図した運動）に関与する神経路の興奮水準を 高め, 同時に患者に示指を伸ばす運動努力を求めて, 患者 の運動努力がその神経路に伝わることを助ける, 示指のみ の伸展 (患者が意図した運動) を実現させたら, さらにそ の運動を反復して神経路を強化し, 促通操作なしでも示指 のみの伸展を可能にする (麻疩の回復).

つまり, 促通反復療法の特徵は治療者が再建 - 強化の目標 とした神経路への興奮伝達を実現して, 選択的に神経路の再 建と強化ができる神経路レベルのリハができることにある ${ }^{1)}$.

治療中, 治療者は患者に「曲げて, 伸ばして」と指示し て運動努力を求め, 同時に促通操作を加えるため, これま で他動運動として行われた関節可動域訓練も促通反復療法 による自他動運動に置き換えられ，同一治療時間で数倍の 運動パターンと運動回数の実施が可能となる. 同一運動パ ターンの反復回数は臨床研究や日常の治療では 50-100 回で ある. 患者には運動速度を上げることより十分に目標の運 動に近づけるためのコントロールを求めている. 健常者と 同じようなバリスチック運動を目指した速い運動は随意性 向上につながらない.

\section{2 片麻痺下肢と歩行}

片麻痺下肢の麻痺と歩行を改善する促通反復療法の基本 的理論と手技は, 片麻痺上肢と同様である. マット上の臥 位で下腿三頭筋, 股関節内転筋の痤縮を振動刺激痤縮抑制 法で抑制した後, 共同運動から分離した運動で, 歩行に関

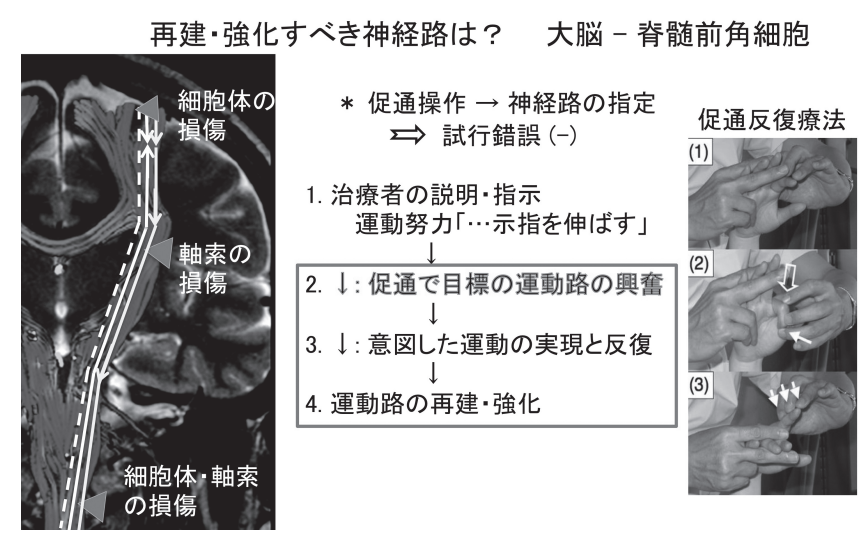

図 3 促通反復療法の治療理論と操作

患者が麻疩手の示指を伸ばそうとしても, 運動野と脊䯣前角細胞を 繋ぐ損傷を免れた神経路（迂回路: 破線）は興奮水準が低く, 示指 の伸展は生じない. しかし, 患者の運動努力の直前に治療者が示指 を素早く曲げて伸張反射で迂回路の興奮水準を上げれば（皮質への 矢印), 患者の運動努力は迂回路へ伝わり示指の伸展が生じる（皮 質からの矢印). 
連した運動パターンを促通下で反復している.

歩行時の安定と歩行速度は, 非麻疩側下肢（健側下肢） での立脚時のバランスと麻疩側下肢の振り出し時のつま先 のクリアランス（床を引きずらない）で決まる。下肢装具 を装着しての健側立脚重視の平行棒内（杖）2動作歩行を重 視する必要がある.

この歩行を実現させるには, 図 4 に示すように, 治療者が 健側の中殿筋をタップして安定した立脚を促し, 同時に麻痺 側下肢の鼠径䩲帯を擦って麻疩肢の振り出しを促す. 次に 麻痺側下肢が着床したら安定して立ち, 重心を健側下肢に 戻せるように麻痺側中殿筋を刺激する歩行促通法を用いる.

\section{3. 促通反復療法の治療効果}

\section{1 片麻痺上肢}

促通反復療法の片麻疩上肢への治療効果は慢性期例 ${ }^{5)}$ と 回復期例 ${ }^{6.7)}$, 急性期例 ${ }^{8)}$ で確認されている. 脳卒中発作後 1 年以上経過した陳旧例での麻瘏改善は困難とされるが, 促 通反復療法の治療効果は, 図 5 に示すように, リ八開始時 に共同運動の分離があった例（図の上段，罹病期間 $59 \pm 48$ 力月）は上肢 (肩肘), 手指の麻疩が大きく改善し, 物品操 作能力を意味する簡易上肢機能検査 (STEF: Simple Test for Evaluating hand Function）も大きく向上した.リハ開始時 に共同運動の分離がなかった重症例（図下段，罹病期間 31 \pm 25 力月）は肩肘のみに改善があった ${ }^{5)}$.

回復期例を対象（罹病期間 3-13 週）に治療（40 分／日， 4 週間）行ったランダム化比較試験で, 促通反復療法群が通 常の作業療法群より麻痺 (FAM: Fugl-Meyer Arm scores) と, 図 6 に示す物品操作能力 (ARAT: Action Research Arm test) の改善が有意に大きかった. ARAT の改善は指先で物品を 操作する “摘む (pinch)”と“掴む (grasp)”が大きかった ${ }^{6}$.

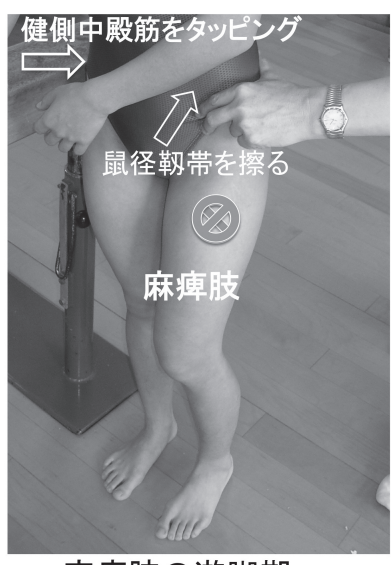

麻痺肢の遊脚期

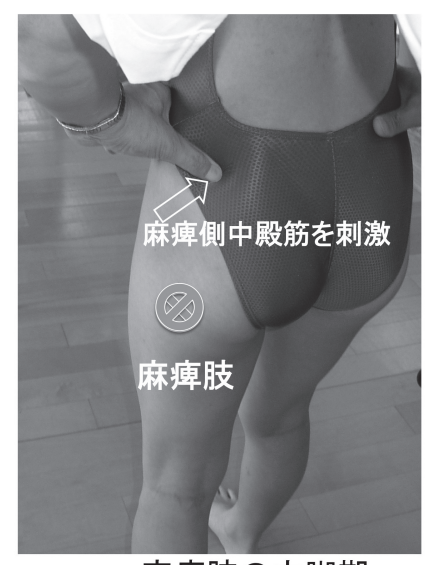

麻痺肢の立脚期
図 4 促通反復療法の歩行促通法 歩行中の促通法は麻痺肢の振り出しと健側立脚を促通するので, 歩 行時のバランスと歩行速度を向上させる。これまで多く行われてき た立位訓練時の両脚均等荷重や歩行時に「麻痺側に体重を掛けて」 の指示は麻痺側下肢の病縮を強め, 健側下肢への円滑な重心移動を 妨げて歩行速度を低下させるので勧められない.

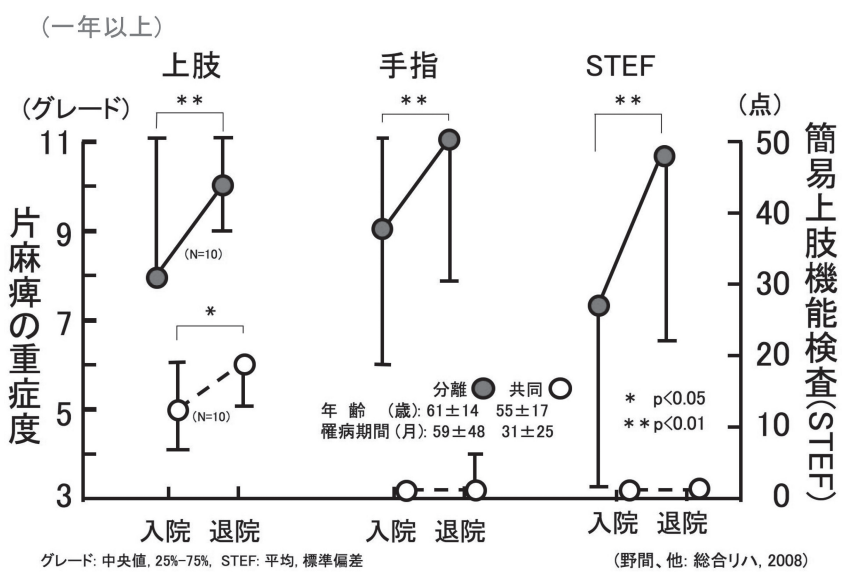

図 5 促通反復療法による慢性期片麻痖の改善 リ八開始時に共同運動の分離があった例（図の上段）は上肢（肩肘） と手指の麻痺, 物品操作能力（簡易上肢機能検査; STEF）も大きく 向上したが，共同運動以下だった例（図の下段）は上肢（肩肘）の み有意に改善した。

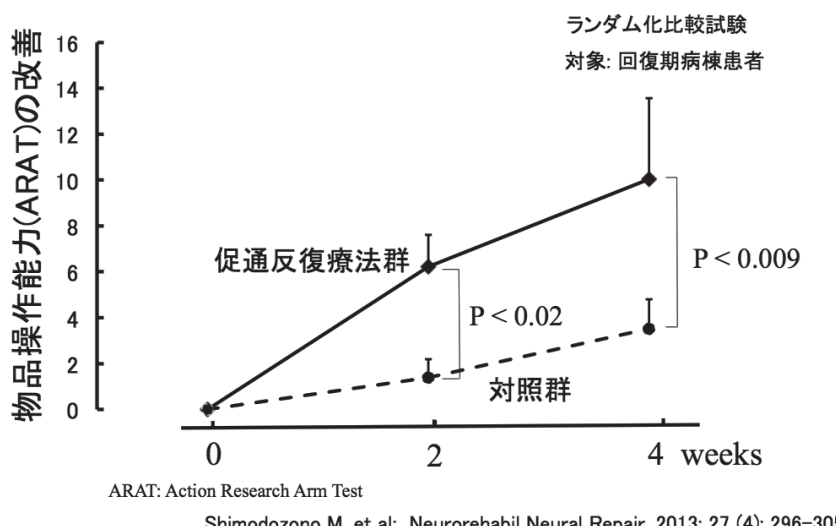

図 6 促通反復療法による物品操作能力の改善

片麻痺上肢の物品操作能力の改善は促通反復療法群が対照群より有 意に大きかった。

\section{2 片麻痺下肢, 歩行, ADL}

促通反復療法と装具療法との併用療法（4 週間）の片麻瘏 下肢と歩行能力への治療効果は慢性期例（罹病期間 : $36 \pm$ 29 力月）を対象にして検討し, 併用療法によって下肢の麻 瘏と歩行速度が改善した ${ }^{9)}$ 。

回復期例を対象とした促通反復法の日常生活活動への効 果もランダム化比較試験での検討が行われた ${ }^{7}$.

ADL の改善は, 図 7 に示すように, 下肢に促通反復療法 を受けた群が通常治療群より日常生活活動を評価する FIM (Functional Independence Measure) の総合得点, 運動項目 の得点とも有意に大きかった.

\section{3 促通反復療法との併用療法 (電気刺激 - 振動刺激 - 経 頭蓋磁気刺激, ボッリヌス療法)}

促通反復療法の効果を高めるため, 治療前に振動刺激 


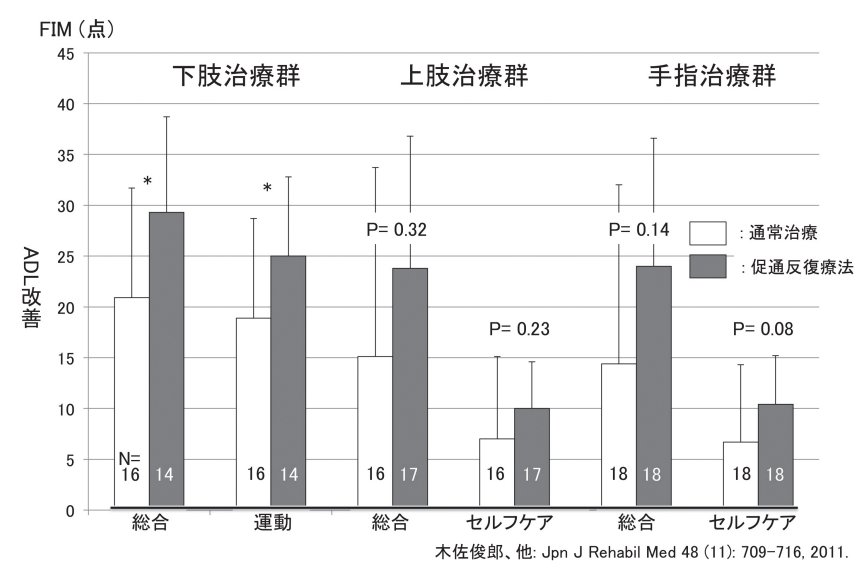

図 7 促通反復療法と通常治療による回復期片麻瘦患者の ADL 改善の比較

促通反復療法と通常治療の日常生活活動への効果を FIM (Functional Independence Measure）で比較すると, 下肢に促通反復療法を受け た群が総合得点, 運動項目の得点とも通常治療より有意に大きな改 善を示した。 上肢や手指に促通反復療法を受けた群は総合得点とセ ルフケア得点が通常治療より優れる傾向があった.

を与えて効果的に痤縮抑制を行う振動刺激㽷縮抑制法 (DAIViS: direct application of vibratory stimuli to the spastic muscles） ${ }^{10)}$ や低周波電気刺激（運動閾值で持続的）下で促 通反復療法 ${ }^{11,12)}$, 経頭蓋磁気刺激 ${ }^{13)}$, ボツリ又ス療法 ${ }^{14)}$ も 併用しており，いずれも大きな効果を得ている.

要点は持続的電気刺激で目標の神経路の興奮水準を運動 䦐值あるいは運動闇值を少し超えるレベルまで高めておく こと, あるいは振動刺激痤縮抑制法やボツリヌス療法で痤 縮筋の脊髄前角細胞の興奮水準を下げ, 痤縮筋の拮抗筋の 興奮水準を上げて, 患者の意図した運動の実現を容易にす ることである。

\section{4. 促通反復療法の治療原理をロボットヘ}

ロボットについては, 障害者の日常生活で欠かせない下 肢装具や自助具の役割をするロボットと, ロボットを用い た訓練によって麻瘏の改善や歩行能力の改善が促進され, 訓練期間の後はロボットが不要になる訓練用ロボットと分 けて考える必要がある。

この訓練用ロボットについては, 同一治療時間で治療効 果を比較するとロボット訓練は通常の理学療法士や作業療 法士が行う訓練を超えるのは難しく, ロボット訓練が大き な効果を示すのは通常の訓練にロボット訓練を上乗せした 場合である．歩行や上肢の特定の運動（リーチングなど） の単一の課題を繰り返し行う場合はロボット訓練が通常の 訓練より有利になる ${ }^{15)}$. しかし, 免荷トレッドミルと正常 歩行を行うロボット訓練と同一条件で理学療法士が指示と 介助を行う歩行訓練とで歩行速度を比較すると, 理学療法士 の訓練が効果的であった ${ }^{16)}$.

これらのロボット訓練の検討結果から，ロボットを用い
学習を効率的に進める $=$ 目標の神経路の形成 - 強化

1) 興奮を繰り返し伝えた神経路は強化

2) 同時に興奮した神経路は結合

$\sqrt{2}$

a) 目標の神経路に選択的に興奮を伝達

方法: 伸張反射など, 持続的電気刺激, 視覚刺激, 聴覚刺激,

b）目標の神経路への興奮伝導を反復

方法: 課題遂行を容易に(免荷·運動補助, 低い難易度)

正確さ: フイードバック (リアルタイム 》終了後)

c) 患者の運動努カとロボットの操作や刺激を同期

方法: 運動開始の指示 (言語〉》非言語; 聴覚 - 身体·視覚刺激, ...) 患者の運動努力を判別（力·運動, EEG, EMG, ...)

\section{凤 \\ 効果的な訓練用ロボット}

図 8 訓練用ロボットに求められる機能 運動学習を効率的に進める訓練用ロボットには，1）と2）の条件を 備えることが望ましい.

たリハビリテーションを効率的に進めるには, 図 8 のように, 学習つまり習得目標の運動に関与する特定の神経路の強化 を重視する必要がある.

現在の多くのロボットが患者に運動努力を求め目標の運 動を達成するのに足らない分をロボットが補助して動かす 機構 (assisted-as-needed control), リハで言う自他動運動を 用いている ${ }^{15)}$.

更に機能を高めるために, 図 9 に示すように, 促通反復 療法と共通する目標の自動運動の実現を容易にする促通機 能の付加と患者の運動努力とロボットの操作を一致させる 機能の工夫が有力であろう ${ }^{15,17)}$. 修得目標の運動の実現を 患者に求める方法として, 信号音や灯の点滅, 重心位置や 着床の位置, モニターに映った患者の全身像や麻痺肢の像

\section{促通反復療法と訓練用ロボットとの共通点} 促通反復療法意図実現型ロボット

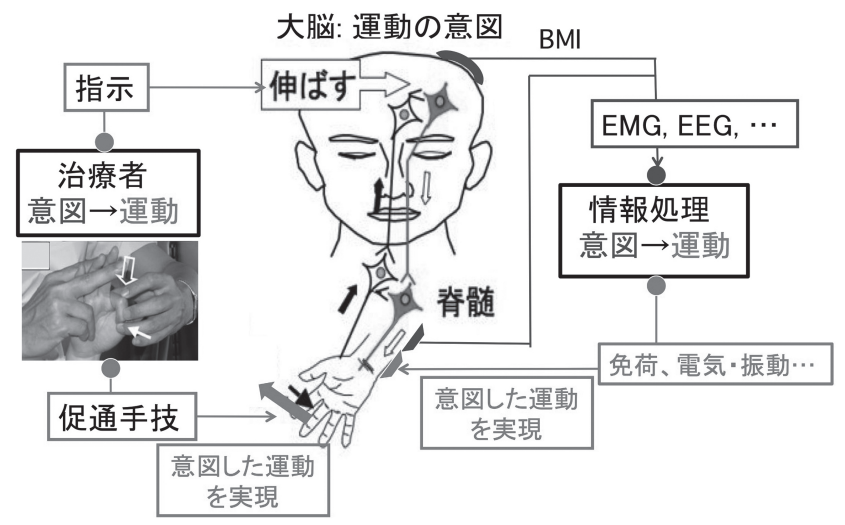

図 9 促通反復療法と意図実現型訓練用ロボット ロボットが患者の運動努力を感知し, 目標の自動運動を実現する促 通機能があれば, 目標の自動運動の実現と反復できる意図実現型口 ボットとなる. 
が用いられることが多いが, 必死に課題を行っている患者 にとって間接的な指示であり, リアルタイムな修正指示を 重視するなら，麻疩肢を見ること，具体的な「体を右へ」 などの言語指示を用いることが効果を高めることになろう。

促通機能によって, 意図した自動運動の実現が容易にで きる意図実現型ロボットは assisted-as-needed control の自動 運動を増大させ, ロボットが他動的に動かす部分が減少す るため, 目標の神経路の再建・強化に有利になる。

上肢訓練用ロボット（上肢訓練装置 AR2, 安川電機）は, 図 10 に示すように, 上肢のリーチング運動をコンピュータ 制御の免荷下で肩と上腕への振動刺激と機能的電気刺激に よる促通を併用した意図実現型ロボットである.

このロボットを用いて頚髄損傷例（66 歳, 男性, 四肢麻痺, 罹病期間 3 カ月）にロボット訓練（リーチング運動, 肩屈 曲と肘屈伸； 20 分）と促通反復療法（肩屈曲 100 回と肘の 屈伸；20 分）との 2 週間ずつのクロスオバー試験を行った.

多くのパラメータで改善があったが, 肩関節の自動運動

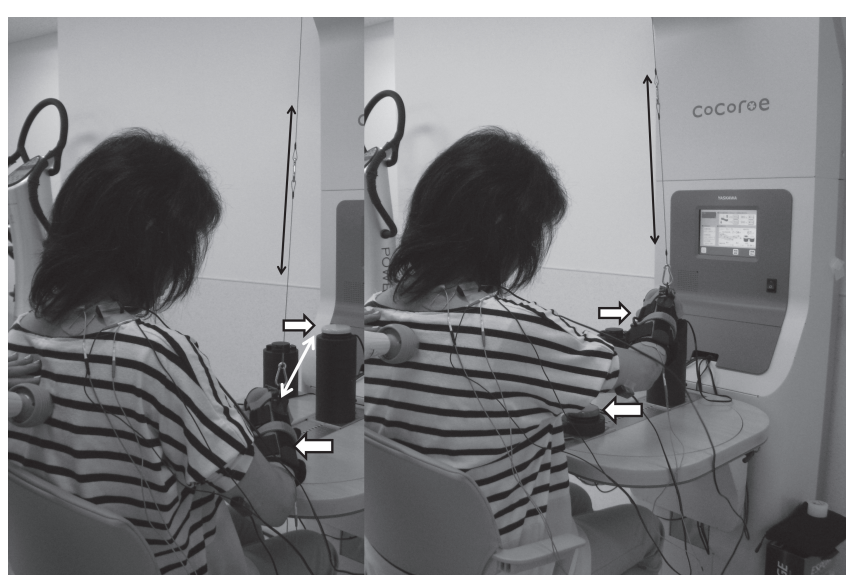

図 10 上肢訓練用ロボット (上肢訓練装置 $\mathrm{AR} 2$, 安川電機) 患者は上前方へのリーチング運動を免荷下（コンピュータ制御）下 で肩と上腕への促通刺激（振動刺激と機能的電気刺激）を受けなが ら行っている．運動方向は目標のスイッチの位置と高さを変更す ることで調整ができる. 目標の運動の実現と反復を援助する促通 機能付き意図実現型ロボットである.

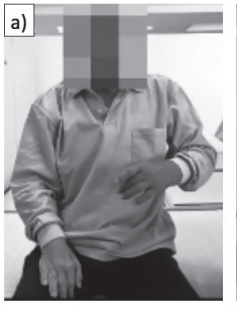

a) 治療前: 発症後3力月， b) 治療(口ボッ卜と促通反復療法) 2ヶ月後, 不全春髄損傷 66 歳, 男性, 四肢麻疸, 罹病期間3力月
図 11 頝髄損傷例へのロボット訓練と促通反復療法の効果 ロボット訓練 (20 分) と促通反復療法 (20 分) の効果を 2 週間ずつ のクロスオバー試験で比較した．右側に示す自動運動の可動域では ロボット訓練が促通反復療法より効果的であった。
での屈曲角度は, 図 11 に示すように, ロボット訓練期間の み改善があった ${ }^{18)}$ 。この改善の差は肩肘の運動が促通反復 療法が 200 回であるのに対しロボット訓練では 400-500 回 行っていることによると考えられた.

つまり，座位で上肢の重さを支えながら上方へのリーチ ングは片麻痺上肢にとって難しい課題であるが，コンピュ ー夕制御の免荷下で「曲げて, 伸ばして」の音声指示に合 わせて, 楽に修得目標であるリーチングを実現反復するロ ボット訓練の優位性を示している.

\section{5. おわりに}

治療者の操作と患者の運動努力を同期させて, 目標の神 経路への興奮伝達を可能にした促通反復療法の治療原理は 多くの併用療法を可能にする他, 今後の訓練用ロボットの 開発につながるであろう。

\section{参考文献}

1) 川平和美, 下堂薗恵, 野間知一: 片麻瘏回復のための運 動療法; 促通反復療法「川平法」の理論と実際. 第三版, 医学書院, (2017).

2) Ueno, M1., Hayano, Y., Nakagawa, H. and Yamashita, T.: Intraspinal rewiring of the corticospinal tract requires target-derived brain-derived neurotrophic factor and compensates lost function after brain injury, Brain, 135(4), 1253-1267, (2012).

3) Antonov, I., Antonova, I., Kandel, E. R. and Hawkins, R.: Activity-dependent presynaptic facilitation and hebbian LTP are both required and interact during classical conditioning in Aplysia, Neuron, 37, 135-147, (2003).

4) 日本脳卒中学会脳卒中ガイドライン編集委員会 : 脳卒中 治療ガイドライン, (2015).

5) 野間知一, 鎌田克也, 海唯子, 溜いずみ, 衛藤誠二, 下 堂薗恵, 緒方敦子, 松元秀次, 川平和美 : 慢性期脳卒中 片麻疩上肢への促通反復療法の効果, 総合リハビリテー ション, 36 (7), 695-699, (2008).

6) Shimodozono, M., Noma, T., Nomoto, Y., Hisamatsu, N., Kamada, K., Miyata, R., Matsumoto, S., Ogata, A., Etoh, S., Basford, JR. and Kawahira, K.: Benefits of a repetitive facilitative exercise program for the upper paretic extremity after subacute stroke: A randomized controlled trial, Neurorehabilitation and Neural Repair, 27(4), 296-305, (2013).

7) 木佐俊郎, 酒井康生, 三谷俊史, 小野惠司：回復期脳 卒中片麻痷患者のリハビリテーションに促通反復療法を 取り入れた場合の片麻痺と日常生活活動への効果; 無作 為化比較対照試験による検討, The Japanese Journal of Rehabilitation Medicine, 48 (11), 709-716, (2011). 
8) 射塲靖弘, 古和久典, 曽田武史, 松本浩実, 松下久美, 中下聡子, 尾謧まり, 萩野浩 : 急性期脳梗塞片麻疩患者 に対する促通反復療法が上肢機能に及ぼす影響, 総合リ ハビリテーション, 43(6), 563-566, (2015).

9) Tomioka, K., Matsumoto, S., Ikeda, K., Uema, T., Sameshima, J., Sakashita, Y., Kaji, T. and Shimodozono, M.: Short-term effects of physiotherapy combining repetitive facilitation exercises and orthotic treatment in chronic post-stroke patients, Journal of Physical Therapy Science, 29, 212-215, (2017).

10) Noma, T., Matsumoto, S., Shimodozono, M., Etoh, S. and Kawahira, K.: Anti-spastic effects of the direct application of vibratory stimuli to the spastic muscles of hemiplegic limbs in post-stroke patients: a proof-of-principle study, Journal of Rehabilitation Medicine, 44(4), 325-330, (2012).

11) Shimodozono, M., Noma, T., Matsumoto, S., Miyata, R., Etoh, S. and Kawahira, K.: Repetitive facilitative exercise under continuous electrical stimulation for severe arm impairment after subacute stroke: A randomized controlled pilot study, Brain Injury, 28, 203-210, (2014).

12) 前迫篤, 長瀬愛美, 長堂竜維, 下堂薗恵, 川平和美 : 脳梗塞急性期における片麻盘上肢への促通反復療法と 持続的低周波電気刺激法の同時併用療法による運動機 能と浮腫の改善, The Japanese Journal of Rehabilitation Medicine, 51(3), 219-227, (2014).

13) Etoh, S., Noma, T., Takiyoshi, Y., Arima, M1, Ohama, R., Yokoyama, K., Hokazono, A., Amano, Y., Shimodozono, M. and Kawahira, K.: Effects of repetitive facilitative exercise with neuromuscular electrical stimulation, vibratory stimulation and repetitive transcranial magnetic stimulation of the hemiplegic hand in chronic stroke patients, International Journal of Neuroscience, Nov;126(11), 10071012, (2016).

14) 奥山優子, 中馬孝容, 緒方敦子, 川平和美 : 慢性期片麻 痺上肢へのボッリヌス毒素療法と促通反復療法との併用 が著効を呈した 1 例, 総合リハビリテーション, 41 (12), 1143-1146, (2013).
15) 川平和美, 余永, 下堂薗恵: リハビリテーションロボッ トに求められるものは?, 日本機会学会誌 119, (1166), 14-16, (2016).

16) Hornby, T. G., Campbell, D. D., Kahn, J. H., Demott, T., Moore, J. L. and Roth, H. R.: Enhanced gait-related improvements after therapist- versus robotic-assisted locomotor training in subjects with chronic stroke: a randomized controlled study, Stroke, 39(6), 1786-1792, (2008).

17) Taniguchi, K., Yu, Y., Noma, T., Yamanaka, H., Fukuda, I., Matsumoto, S., Shimodozono, M. and Kawahira, K.: Training condition research on selective DOF constrainable rehabilitation unit with shrinkable electrical and vibratory stimulation timing and duration control system for hemiplegic shoulder-flexion and elbow-extension, Proceedings of the 2016 IEEE International Conference on Robotics and Biomimetics, 158-167, (2016).

18) Hoei, T., Kawahira, K., Fukuda, H., Shgenobu, K., Shimodozono, M. and Ogura, T.: Use of an arm weightbearing combined with upper-limb reaching apparatus to facilitate motor paralysis recovery in an incomplete spinal cord injury patient: A single case report, Journal of Physical Therapy Science, 29, 176-180, (2017).

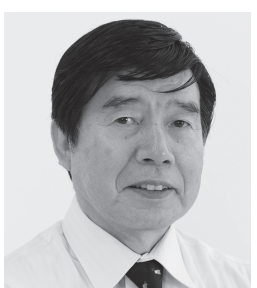

川平和美（かわひらかずみ） 1974 年鹿児島大学医学部卒業, 1982 年 医学博士学位取得, 2005 年鹿児島大学 大学院機能修復学講座リハビリテーショ ン医学, 教授. 2013 年鹿児島大学大学院 を定年退職. 現在, 藤田保健衛生大学大 学, 国際医療福祉大学の客員教授, 促通反復療法研究所所 長. 主として, 促通反復療法による診療, 教育, 研究, 口 ボットの開発に従事. 日本リハビリテーション医学会, 日 本ニューロリハビリテーション学会の会員, 再生医療とリ ハビリテーション研究会の代表理事. COI：(株) 安川電機 顧問. 